Wojciech TEISTER

Ks. Andrzej UCIECHA

(Katowice, UŚ)

\title{
POSTAWA CHRZEŚCIJAN KOŚCIOLA PERSKIEGO W CZASIE PRZEŚLADOWAŃ SZAPURA II
}

Temat artykułu dotyczy perskich chrześcijan w okresie prześladowań Szapura II. Wywodzący się z dynastii Sasanidów monarcha ten rządził Królestwem perskim w latach 309-379, na czas jego rządów przypada szczytowy okres potęgi państwa Sasanidów ${ }^{1}$. Władca ten, posługujący się tytułem szachinszach, prowadził wojny z Cesarstwem rzymskim, a w ramach polityki wewnętrznej wzmocnił wpływy mobedów, to znaczy kapłanów Ahuramazdy, oraz uczynił zoroastryzm religią panującą. Żaden z tych faktów nie pozostał bez znaczenia dla chrześcijan perskich. W roku 340 z rozkazu króla rozpoczęły się krwawe prześladowania wyznawców Chrystusa, które trwały praktycznie aż do śmierci monarchy ${ }^{2}$. Najistotniejsze zachowane relacje o tych wydarzeniach możemy znaleźć w Historii Kościoła Sozomena ${ }^{3}$, w Mowach Afrahata ${ }^{4}$ oraz w Chronica Seertensis, nestoriańskiego autora z IX lub X wieku'.

Afrahat, zwany także Mędrcem Perskim, był rodowitym Persem piszącym swoje dzieła w języku syryjskim. Był prawdopodobnie przełożonym ,synów przymierza”, ascetycznej grupy chrześcijan perskich. Napisał 23 Mowy, których adresatami są właśnie „synowie przymierza”. W niektórych z nich znaleźć możemy aluzje do sytuacji prześladowanego Kościoła. Afrahat pisze jako naoczny świadek tych wydarzeń, przez co jego relacja nabiera szczególnej wartości.

Historyk Sozomen tak oto opisuje początki represji chrześcijan:

\footnotetext{
${ }^{1}$ Por. B. Składanek, Historia Persji, t. 1: Od czasów najdawniejszych do najazdu Arabów, Warszawa 2008, 215.

${ }^{2}$ Por. A. Uciecha, Postawa duchowieństwa Kościoła Perskiego w czasie prześladowań Szapura II, w: Vobis Episcopus vobiscum christianus. Ksiega Jubileuszowa ks. abpa Damiana Zimonia, red. W. Myszor - A. Malina, Katowice 2004, 279.

${ }^{3}$ Por. Hermias Sozomenus, Historia ecclesiastica, ed. J. Bidez - G.C. Hansen, GCS 50, Berlin 1960, thum. S. Kazikowski, wstęp Z. Zieliński, Warszawa 1980.

${ }^{4}$ Por. Aphraates, Demonstrationes I-XXIII, ed. J. Parisot, PSyr 1-2, Paris 18941907 (tekst syryjski i tłumaczenie łacińskie).

${ }^{5}$ Historia Nestoriana (Chronica Seertensis), ed. A. Scher - J. Périer, PO 4, fasc. 3 - n. 17, Turnhout 1981, s. 215-312 (tekst arabski i przekład francuski).

${ }^{6}$ Por. Uciecha, Postawa duchowieństwa, s. 279.
} 
„Zaczęli zbierać się na nabożeństwa, mając już własnych kapłanów i diakonów. Fakt ten niezmiernie zaczął drażnić magów, którzy niby jakiś szczep kapłański, na zasadzie rodowego dziedzictwa przechodzącego z ojca na syna, od dawien dawna opiekują się religią perską. Bolało to i Żydów w jakiś sposób z natury wrogo usposobionych do nauki chrześcijańskiej pod wpływem zazdrości. Toteż jedni i drudzy składają przed Saporem, ówczesnym królem, oszczercze oskarżenia pod adresem Symeona, który był wtedy arcybiskupem Seleucji i Ktezyfontu, dwu najważniejszych miast w Persji, obwiniają go, że będąc przyjacielem cesarza Rzymian, donosi mu o wszystkim, co się dzieje u Persów. Przekonany oszczerstwami Sapor, najpierw zaczął uciskać chrześcijan niezmiernymi podatkami, bo wiedział, że są to przede wszystkim ludzie uprawiający ewangeliczne ubóstwo; przy czym ściąganie należności zlecił ludziom nieubłaganym; w rezultacie przymuszeni brakiem pieniędzy i bezwzględnością poborców wzgardzić mieli własną wiarą, a przecież o to mu przede wszystkim chodziło"7.

Hermiasz Sozomen był obrońcą sądowym w Konstantynopolu za panowania Teodozjusza II (408-450) ${ }^{8}$, a bezpośredniej przyczyny prześladowań doszukiwał się w zawiści magów i Żydów. Reakcję pierwszych autor wyjaśnił jako próbę obrony własnych rodowych interesów. Prawdopodobnie wzrost liczby chrześcijan i wynikający z tego spadek wyznawców zoroastryzmu mógł mieć negatywne skutki ekonomiczne dla tej grupy społecznej. Nieco trudniej zrozumieć reakcję Żydów, którą Sozomen tłumaczył zwyczajną, szczerą nienawiścią.

Jako pretekst prześladowań przytoczył ten historyk oskarżenie biskupa Symeona o szpiegostwo na rzecz Rzymian, z którymi Persowie toczyli w tym czasie długotrwałe wojny, choć sam jest przekonany o tym, że biskup jest niewinny. Warto jednak wziąc pod uwagę perspektywę jego dziejopisarstwa, które dedykowane było Teodozjuszowi i w całym utworze tendencyjnie skłonne do podkreślania pozytywnego wizerunku rzymskich władców, przy równoczesnej krytyce ich przeciwników ${ }^{9}$. Trudno zatem wyobrazić sobie, aby będący w konflikcie z Cesarstwem perscy niechrześcijanie zostali przedstawieni w dobrym świetle. Trudno też odpowiedzieć, na ile ocena Sozomena jest trafna. Należy tu bowiem rozważyć przynajmniej dwie możliwości. Być może Sozomen nie minął się z prawdą i prześladowania były następstwem zawiści i oszczerstwa. Istnieje jednak także inna możliwość: represje mogły być elementem składowym szerszej wizji politycznej, której celem byłoby wzmocnienie perskich tradycji kulturowych i ograniczenie jakichkolwiek wpływów rzymskich. Chrześcijaństwo, które od momentu wydania w 313 r. reskryptu mediolańskiego stało się w Cesarstwie rzymskim religią równoprawną mu-

\footnotetext{
${ }^{7}$ Sozomenus, HE II 9, 1-2, GCS 50, 61-62, thum. Kazikowski, s. 97-98.

${ }^{8}$ Por. Z. Zieliński, Wstęp, w: Hermiasz Sozomen, Historia Kościoła, tłum. S. Kazikowski, Warszawa 1980, 7.

${ }^{9}$ Por. Zieliński, Wstęp, s. 8; zob. P. Devos, Sozomène et les Actes syriaques de Syméon bar Sabba'e, AnBol 84 (1966) 443-456.
} 
siało być w imperium Sasanidów kojarzone z Rzymem: chrześcijan oskarżano o współpracę z nieprzyjacielem ${ }^{10}$.

Afrahat, mędrzec perski, relacjonuje swoją wersję wydarzeń. W mowie V: $O$ wojnach znajduje się następujący tekst:

„Bóg bowiem uprzednio wyznaczył te czasy: chwile pomyślności spełniające się w dniach [ludzi] dobrych i prawych; chwile zaś wielu nieszczęść, nadchodzące w dniach [ludzi] złych i grzesznych. Otóż tak jest napisane: Dobro już gotowe i błogosławiony ten, przez którego ono przyjdzie; i zło już przygotowane, lecz biada temu, przez którego przyjdzie. [...] Nie zarzucaj więc, mój drogi, iż Zły rzucił zło na wielu, ponieważ czasy są wyznaczone od dawna i nadeszła chwila ich wypełnienia" 11 .

Mędrzec perski za punkt wyjścia swoich rozważań przyjmuje historię zbawienia, a jego teksty nacechowane są perspektywą eschatologiczną. Prześladowania, choć są dla wyznawców Chrystusa czasem trudnym, to jednak z dawna zapisanym w Bożym planie. „Chwile nieszczęść” zaś nadeszły w czasach ludzi grzesznych, rzeczywistą więc przyczyną represji są grzechy ludzkie, a sam fakt prześladowań jest wtórny i ma wymiar oczyszczający.

Jeszcze wyraźniej widać to w Liście synodalnym, w którym zwracając się do adresatów Afrahat pisze:

„Chcemy was powiadomić, bracia i przyjaciele, i gdy tylko wam oznajmimy również i my sami sobie przypomnimy to, co wydarzyło się w naszych dniach z powodu naszych grzechów, które pomnożyły się, umocniły i zwiększyły ból"'12.

Afrahat nie poszukuje winnych „na zewnątrz” chrześcijańskiej wspólnoty, ale rewizję rzeczywistości zaczyna od rzetelnego rachunku sumienia. Zdaje się mówić, że to „my” jako wspólnota Kościoła popełniliśmy grzechy, a bieżące wydarzenia są tylko ich konsekwencją.

Jakie jednak przewinienia ma na myśli nasz Pers? Odpowiedź znaleźć możemy również w Liście synodalnym:

„Powstali oto w naszym ludzie przywódcy, którzy porzucili prawo i wychwalali się w nieprawości. Zdobyli majętność/władzę i pokonała ich chciwość. Pożyczają na procent/lichwa i biorą odsetki; i nie ma nikogo, kto przypomni, co jest napisane: «Nie będziesz brał odsetek ani na procent/lichwy» (Kpł 25, 36) i «Kto chce zamieszkać w przybytku Pana, nie daje swoich pieniędzy na lichwę» (Ps 15, 5). Powiedziano też: «Ten, kto nie bierze lichwy, ani nie poży-

${ }^{10}$ Por. J. Neusner, Babylonian Jewry and Shapur II's persecution of Christianity from 339 to 379 A. D., w: „Hebrew Union College Annual” 43 (1972) 79. Najprawdopodobniej Neusner wykorzystuje wiadomości zawarte w dokumencie z IX (X?) wieku - Chronica Seertensis.

${ }^{11}$ Aphraates, Demonstratio V: De bellis 1, PSyr 1, 184-185, thum. A. Uciecha, ŚSHT 43 (2010) z. 2, 250 .

${ }^{12}$ Aphraates, Demonstratio XIV: Exhortatoria 2, PSyr 1, 573-726, thum. A. Uciecha (w rękopisie). 
cza dla odsetek» (Ez 18, 8), i nie popełnia żadnej z tych obrzydliwości, które wylicza Ezechiel, «w tym upodobał sobie Bóg». W tym teraz czasie są ludzie, którzy kierują się przemocą i nadużywają prawa, są stronniczy. Usprawiedliwiają winnych, a niewinnych potępiają; kochają bogaczy, a biednych nienawidzą; pasą samych siebie, a rozpraszają owce; świat ich zaślepił. Kochają łapówki; wypędzają prawość; nienawidzą upomnienia; kochają bezbożność; nienawidzą pokornych, a kochają wyniosłych, pysznych i próżnych. W ich dniach światło pociemniało a sól utraciła smak, doktrynę ogarnął mrok, prawo zniknęło, winnicę zniszczono, ciernie porosły; ludzie zasnęli i Zły posiał chwast, powstały fale i wzmogły się burze, woźnice padli i rydwany wpadły w zamieszanie; żeglarze posnęli i zatonęły ich łodzie. Prawo skrępowano i zaplombowano świadectwo. I stał się kapłan jak lud. Książęta żądają złota a sędzia orzeka przez łapówkę; wielki przemawia dla swej przyjemności; gardzą biednymi i niszczą nieszczęśliwych w kraju. Gryzą swoimi zębami, głosząc pokój; a jeśli ktoś nie wrzuci im czegokolwiek do ust, ogłaszają wojnę przeciw niemu. Odrzucają sądy i przekręcają wszystko, co sprawiedliwe. Krwią budują Syjon i nieprawością Jeruzalem"13.

Pers wysuwa poważne oskarżenia pod adresem niektórych współwyznawców. Wśród grzechów głównych Afrahat wylicza: lichwę, korupcję, niesprawiedliwe sądy, chciwość, stosowanie przemocy, brak troski o biednych, a przede wszystkim - co jest skutkiem wcześniejszych grzechów - zniszczenie winnicy Pańskiej poprzez zaciemnienie doktryny chrześcijańskiej. Odpowiedzialność za czystość doktryny spoczywała na duchownych, więc to pod ich adresem skierowane są w dużej mierze te zarzuty.

W innym miejscu cytowanej mowy, autor w ironiczny sposób wspomina o pewnym przełożonym, który zamiast troszczyć się o lud, zaczął „rozdawać mu łańcuchy i więzy"14. Zarzuca mu niesprawiedliwe sądy i zwykłą głupotę. Niektórzy badacze identyfikują go z Symeonem, biskupem Seleucji i Ktezyfontu, którego w zupełnie innym świetle stawiał Sozomen ${ }^{15}$. Biskup ten prawdopodobnie współpracował z władzą, był nawet określany mianem „przyjaciela Szapura”. Późniejszą, męczeńską śmierć Symeona tłumaczy się odmową płacenia haraczu na rzecz państwa ${ }^{16}$, Afrahat zaś odmową posłuszeństwa takiemu biskupowi i uzasadnia swoje stanowisko przykładami biblijnymi ${ }^{17}$. Do takiej sytuacji przyczyniła się ogólna niezgoda i nienawiść wśród chrześcijan. Choć bezpośrednia wina leży po stronie niektórych hierarchów, to jednak Pers podkreśla, że jest to tylko skutek braku jedności ludu Bożego. Przyczyn prześladowań Afrahat upatruje w niewierności chrześcijan, a biorąc

${ }^{13}$ Tamże XIV 3, PSyr 1, 577-580.

${ }^{14}$ Tamże XIV 8, PSyr 1, 589.

${ }^{15}$ Por. M.J. Pierre, Introduction, w: Aphraate le Sage Persan. Les Exposes I-X, SCh 349, Paris $1988,87-88$.

${ }^{16}$ Por. Uciecha, Postawa duchowieństwa, s. 285.

${ }^{17}$ Por. tamże. 
pod uwagę jego silne zakorzenienie w Piśmie Świętym, nie należy traktować tej opinii jako metafory.

Ofiary prześladowań znaleźć można w każdej grupie społecznej, w pierwszej jednak kolejności represjom poddawani byli ,synowie i córki przymierza". Najwięcej świadectw dotyczy właśnie tej grupy w Kościele perskim i to zarówno w relacji Sozomena, jak i Afrahata. „Synowie przymierza” należeli do osobnej grupy wczesnochrześcijańskich ascetów, których nie należy identyfikować z mnichami ${ }^{18}$. Żyli w miastach, przy chrześcijańskich świątyniach, i pełnili w nich niektóre funkcje liturgiczne, nie można ich jednak utożsamiać również z duchowieństwem; był to więc ruch dobrze zorganizowany i zurbanizowany. Być może władza obawiała się buntu ze strony tej grupy społecznej, bo znamy przypadki takich buntów w Egipcie.

Afrahat kieruje do swoich adresatów szereg zaleceń, dotyczących sposobu postępowania w czasie prześladowań. Są to wskazówki o charakterze duchowym i dyscyplinarnym. W mowie $O$ modlitwie podaje liczne przykłady modlitwy w ucisku, która przynosi wyzwolenie. Wymienia m.in. Daniela, którego modlitwa sprawiła, że zakończyła się niewola w Babilonie ${ }^{19}$ oraz Eliasza, o którym pisze:

„Eliasz był też tylko sam na górze Karmel, a jego modlitwa ukazała cudowną moc. Dzięki jego modlitwie zamknęły się niebiosa i również przez jego modlitwę zostały uwolnione ich więzy. Jego modlitwa uwolniła z rąk śmierci i wyrwała z szeolu. Nadto jego modlitwa wypleniła nieczystość z Izraela"²0.

Pers jest głęboko przekonany o sile i skuteczności szczerej modlitwy opartej na zaufaniu Bogu.

Innym istotnym zaleceniem duchowym jest post. Afrahat przytacza przykład Mardocheusza i Estery, których post stał się „,tarczą zbawienia dla wszystkich synów ich ludu" ${ }^{21}$. To czysty post sprawił, że biblijni bohaterowie nie tylko przetrwali krwawe prześladowania, ale nawet wyszli z nich jako triumfujący, a ich oprawcę, Hamana spotkała sprawiedliwa kara ${ }^{22}$. Jako przykład dobrego postu wskazany zostaje również Daniel. Pościł on trzy tygodnie za swój lud, aby nie przebywał już dłużej w niewoli i prośba jego została wysłuchana przez Pana ${ }^{23}$.Nie każdy jednak post jest właściwy. Mędrzec tak ujmuje istotę dobrego postu:

${ }^{18}$ Por. A. Uciecha, Rola i znaczenie „,córek przymierza” w Kościele perskim w IV $i$ V w., VV 19 (2011) 233.

${ }^{19}$ Por. Aphraates, Demonstratio IV: De oratione 9, PSyr 1, 156-157, thum. A. Uciecha, ŚSHT 43 (2010) z. 1, 39 .

${ }^{20}$ Tamże IV 12, PSyr 1, 164, thum. Uciecha, s. 40.

${ }^{21}$ Aphraates, Demonstratio III: De ieiunio 1, PSyr 1, 97-136, tłum. A. Uciecha, ŚSHT 42 (2009) z. 1,92 .

${ }^{22}$ Por. tamże III 12, PSyr 1, 124-125, tłum. Uciecha, s. 94.

${ }^{23}$ Por. tamże III 14, PSyr 1, 129, thum. Uciecha, s. 95. 
„Zawsze więc, mój drogi, gdy się pości, powstrzymywanie się od nieprawości lepsze jest niż rezygnacja z chleba i wody"24.

Istotą zatem postu jest skierowanie serca ku Bogu, a nie katowanie swojego ciała. Kolejną cenną wskazówką jest konieczność przebaczenia prześladowcom. Tematu tego pośrednio dotyczy cała mowa II $O$ mitośc $i^{25}$.

We wspominanej już mowie IV $O$ wojnach Afrahat metaforycznie opisuje zaistniałą sytuację:

„Jeśli wojska [prześladowcy] powstają i zwyciężają, wiedz, że jest to upomnienie Boże. Jeśli zwyciężają, zostaną potępione przez sprawiedliwy sąd. Trzeba bowiem, abyś wiedział, że bestia zostanie zabita w swoim czasie. Ty zaś, mój bracie, dołóż teraz starań do troski o miłosierdzie, aby pokój zapanował nad ludem Bożym ${ }^{26}$.

Są to wyraźne słowa otuchy. Prześladowca zostanie pokonany, gdyż Bóg jest sprawiedliwy. Ta nadzieja powinna być obecna w sercach prześladowanych chrześcijan i z tą nadzieją mają nawet $\mathrm{w}$ trudnych czasach realizować przykazanie miłości.

W Mowach Afrahata możemy znaleźć również kilka wskazówek dyscyplinarnych, choć mają one charakter wtórny względem wskazań duchowych. Przede wszystkim prawdziwi wyznawcy Chrystusa powinni z pokorą przyjąć czas prześladowań, jako element Bożego planu zbawienia. Należy wystrzegać się narzekania, gdyż czas ten został wyznaczony od dawna i w tym momencie właśnie się realizuje ${ }^{27}$.

Innym wskazaniem przyczyny prześladowań jest zakaz oddawania pokłonu innym bogom. Represji można było uniknąć poprzez złożenie pokłonu przed królem jako bogiem utożsamianym ze słońcem ${ }^{28}$. W mowie III $O$ poście znaleźć możemy następujące stwierdzenie:

„Zdarza się, mój drogi, że niektórzy stawiają zarzut przeciw Mardocheuszowi, mówiąc: dlaczego nie uczcił Hamana, którego czczono w całym królestwie? Czyż stałaby mu się krzywda, gdyby oddał jemu cześć? I tak mówią: Gdyby Mardocheusz uczcił Hamana, nie podjęto by tak wielkiego zła przeciw Mardocheuszowi i przeciw synom jego ludu. Tak właśnie mówi ten, kto nie pojął istoty sprawy. Mardocheusz bowiem tak postąił jako mąż sprawiedliwy, który strzegł Prawa [...]. Gdyby oddał cześć Hamanowi złoczyńcy, spadłby na niego gniew tak, jak na Saula"29.

${ }^{24}$ Tamże III 8, PSyr 1, 113, thum. Uciecha, s. 92.

${ }^{25}$ Por. Aphraates, Demonstratio II: De caritate, PSyr 1, 48-96, thum. A. Uciecha, ŚSHT 39 (2006) z. 1, 53-67.

${ }^{26}$ Aphraates, Demonstratio V; De bellis 25, PSyr 1, 237, thum. Uciecha, s. 261.

${ }^{27}$ Por. tamże V 1, PSyr 1, 184, thum. Uciecha, s. 250.

${ }^{28}$ Por. Sozomenus, HE II 9, GCS 50, 62-63, tłum. Kazikowski, s. 97-102

${ }^{29}$ Aphraates, Demonstratio III: De ieiunio 12, PSyr 1, 124-125, thum. Uciecha, s. 94. 
Afrahat zatem surowo zakazuje nie tylko oddawania pokłonu, ale wszelkich ustępstw względem prześladowców, nakazując absolutną wierność prawu Bożemu. Prawdopodobnie wśród „synów przymierza” istniała grupa skłonna iść na pewne ustępstwa względem Szapura, traktując tego typu zachowanie jako wybór mniejszego zła.

Zastanawiające są również pojawiające się często w pismach Perskiego Mędrca wątki antyjudaistyczne. Choć wyznawcy religii Mojżeszowej nie sprawowali oficjalnego państwowego kultu, to jednak nie dotknęły ich krwawe represje; te spadły na chrześcijan. Sytuacja taka zdaje się potwierdzać wspominaną tezę, wedle której wyznawcy Chrystusa byli podejrzewani o współpracę z Rzymem. Afrahat surowo zakazał powrotu do religii Mojżeszowej, choć $\mathrm{w}$ dobie prześladowań była $\mathrm{z}$ pewnością taka pokusa. Prawdopodobnie istniały też spore napięcia między obecnymi w społeczeństwie perskim judeochrześcijanami, a pozostałymi wyznawcami Jezusa.

W świetle relacji Afrahata widzimy, że prześladowania chrześcijan w monarchii Szapura II były zjawiskiem złożonym. Niewystarczająca wydaje się być hipoteza, doszukująca się przyczyn wyłącznie w polityce wzmocnienia zoroastryzmu, gdyż takie rozwiązanie ściagnęłoby prześladowania również na Żydów. Nie bez znaczenia była sytuacja napięcia między Persją a Rzymem, w którym chrześcijanie cieszyli się coraz większymi przywilejami.

Represje dotknęły różnych warstw społecznych, w pierwszej jednak kolejności szykanowano społeczność „synów przymierza” i prosty lud. W Kościele Seleucji i Ktezyfontu wyznawcy Chrystusa byli podzieleni. Afrahat był świadkiem głębokiego konfliktu między hierarchią a wiernymi Kościoła; nie był to jednak, jego zdaniem, powód do porzucenia wiary. Wręcz przeciwnie, zachęcał on swoich podwładnych do pokornego podporządkowania się woli Bożej i szczerej modlitwy o sprawiedliwość; wzywał do konsekwentnej wiary, nawoływał do postu i pokuty, upatrując w prześladowaniach konsekwencji grzechów Kościoła. Czas represji był dla niego okresem próby i oczyszczenia. Równie mocno był jednak przekonany o tym, że niebawem nadejdzie sprawiedliwość, prześladowców oraz niewiernych spotka zasłużona kara, zaś tych, którzy byli wierni - zasłużona nagroda.

Oprócz Sozomena i Afrahata czasy prześladowań chrześcijan w Persji pod panowaniem Szapura II opisuje anonimowy autor z IX albo X wieku. W swoim dziele Chronica Seertensis, napisanym po arabsku, ten nestorianin wiele uwagi poświęcił męczeństwu metropolity Symeona (Shim oun Bar Sabbai) ${ }^{30}$. Przyszły przywódca perskich chrześcijan urodził się w rodzinie królewskich farbiarzy w Suzie albo w Seleucji-Ktezyfontu. Najpierw był archidiakonem metropolity Papasa, a gdy ten został sparaliżowany, zarządzał majątkiem Kościoła. Gdy metropolita popadł w konflikt (autor Chronica nie podaje jego przyczyn) ze swoimi biskupami i wiernymi, przymuszono Symeona i ustanowio-

${ }^{30}$ Historia Nestoriana (Chronica Seertensis), ed. A. Scher - J. Perier, PO IV 296-305 (Historia Simeonis Barsabbae martyris). 
no go nowym metropolita. Papas upomniał bezprawnie wybranego Symeona, przepowiadając mu, jako akt ekspiacji za spowodowanie rozłamu w Kościele, jego męczeństwo. W charakterze rozjemców w sporze wystapili Grecy, czyli najprawdopodobniej trybunał odwoławczy metropolity Antiochii Syryjskiej. Papas pozytywnie odpowiedział na wezwanie owych Greków i zgodził się, aby jego następcą został Symeon. Gdy metropolita zmarł, biskupi zebrani w $316 \mathrm{r}$. w Seleucji-Ktezyfoncie ustanowili oficjalnie Symeona nowym zwierzchnikiem Kościoła w Persji ${ }^{31}$. Jego duszpasterska praca i postępowanie budzi uznanie autora Chronique de Seért: cały swój majątek, który otrzymał w spadku po rodzicach, rozdał ubogim; przywracał dyscyplinę w Kościele; zabronił mniszkom wspólnych modlitw z mężczyznami podczas nocnych czuwań w uroczystości; diakonom zaś i kapłanom nakazał wypełnianie wszystkich ich obowiązków ${ }^{32}$.

W latach czterdziestych IV wieku zmieniła się sytuacja polityczna w państwie Sasanidów. Szapur II przegrał bitwę o Nisibis w starciu z wojskami cesarza Konstancjusza II (,dzięki modlitwie Jakuba, biskupa Nisibis”) i gorycz porażki przelał na swoich chrześcijańskich poddanych. W kontekście zmian politycznych w królestwie perskim nestoriański historyk opisuje rolę Żydów, którzy wykorzystali nieprzychylne nastawienie szachinszacha wobec chrześcijan. „Przyjaciele szatana”, jak nazywani są Żydzi w Chronica, oskarżyli Symeona o nawracanie przywódców magów oraz osobistości dworu królewskiego na chrześcijaństwo ${ }^{33}$.

Sam król królów przedstawiony został jako największy okrutnik, przeklęty rzeźnik o kamiennym sercu, który nie oszczędził żadnego chrześcijanina; nakazał wrzucać do więzień i lochów, skazywał na głód i pragnienie, na śmierć krzyżową i od miecza. Anonimowy historyk podaje przykład ciężarnej kobiety, której rozcięto brzuch, a wyrwane dziecko rozerwano na dwoje i ukrzyżowano wraz z matką. Władca zabronił pochówku zamęczonych chrześcijan: należało ich ukrzyżować i zostawić, aby byli przestrogą dla innych ${ }^{34}$. W historycznej narracji prześladowania Kościoła w Persji, nestoriański autor umieścił też wątki teologiczne: Szapur porównany został do wilka w owczej skórze, a jego postępowanie przypomina żarłocznego lwa i drapieżnego orła. Takimi obrazami symbolizującymi okrucieństwo posługiwali się prorocy Daniel $(7,4 \mathrm{nn})$ i Ezechiel (17,3.7), opisując króla babilońskiego Nabuchodonozora. Tak czasy niewoli babilońskiej Narodu Wybranego, jak prześladowanie chrześcijan przez perskiego tyrana, należy odczytywać jako doświadczenie i umocnienie wiary. Anonim w prosty sposób stara się podać teologiczną wykładnię męczeństwa: Bóg nie zapomniał o swoim Kościele, ale tylko czasowo zawiesił prawa swojego przymierza i tylko czasowo oddalił aniołów stróżów ${ }^{35}$. Oprócz

\footnotetext{
${ }^{31}$ Por. tamże, s. 296.

32 Por. tamże, s. 298.

${ }^{33}$ Por. tamże, s. 297; zob. też Neusner, Babylonian Jewry, s. 79.

${ }^{34}$ Por. Historia Nestoriana 27, PO IV 298-299.

${ }^{35}$ Por. tamże, s. 298.
} 
ksiąg prorockich w biblijnej argumentacji autor odwołał się do przykładów z pierwszej Księgi Machabejskiej 7,17 i Księgi Psalmów 79(78),2. Porównanie chrześcijan do żydowskich męczenników, ma wyraźny charakter polemiczny, a Kościół przedstawiany jest w tej prezentacji jako nowy Naród Wybrany. Wykorzystanie tekstów Starego Testamentu, wydaje się jasne w kontekście polityczno-religijnej konfrontacji perskiego chrześcijaństwa i babilońskiego judaizmu. Gdy nestoriański historyk wraca do opisu dziejów Symeona, kolejny raz wspomina o dworskich intrygach „przyjaciół szatana”: Żydzi oskarżali metropolitę o sprzeciwianie się rozkazom króla ${ }^{36}$. W konsekwencji Szapur nakazał mu nałożyć podatek od każdego mnicha przebywającego w klasztorze oraz podwoił podatek od każdego wierzącego, nadto zarządził kontrybucję na moczary i bagna w kraju ${ }^{37}$. Metropolita dwukrotnie odmówił królowi ${ }^{38}$. Ten w końcu zażądał, aby Symeon wyrzekł się swojej wiary, a przyjął religię słońca i ognia. Z powodu oporu Szapur skazał Symeona i jego towarzyszy na śmierć przez ścięcie ${ }^{39}$. Dzielny hierarcha w więzieniu umacniał idących na śmierć, wśród których znajdował się kapłan Ananiasz, który przed swoim męczeństwem modlił się:

„Błogosławię Boga, który ukazał mi koronę moich braci i dzięki składam Chrystusowi, który nie pozwolił, abym stracił ani jedno z moich dzieci. Modlę się za wszystkich i za tę ziemię, która przyjęła krew męczenników. /.../ Panie, Boże, spraw, aby ta ziemia stała się pełna miłosierdzia (przez krew i ciała męczenników), a ten muł/błoto usunął choroby ciała"40.

W przeddzień swojej śmierci Symeon odprawił mszę. Za ołtarz posłużyły mu plecy jednego z uwięzionych kapłanów: patenę położył po prawej stronie, zaś kielich po lewej stronie ${ }^{41}$. Autor wyraźnie stylizuje opis hagiograficzny Symeona i jego męczeństwo na wzór pasji Chrystusa (śmierć w piątek o godzinie dziewiątej; ciało zabrano w nocy i pochowano w tajemnicy; na miejscu śmierci Shim'oun Bar Sabbai powstał pagórek - mała Golgota? $)^{42}$. W historycznym przekazie znalazła się również wzmianka o relikwiach męczenników. Biskup Ledan porozdzielał fragmenty ich ciał i skrwawionych ubrań, i porozsyłał do kościołów. Wierzono w ich cudowne działanie: przywracały zdrowie i uzdrawiały chorych ${ }^{43}$.

\footnotetext{
${ }^{36}$ Por. tamże, s. 299.

${ }^{37}$ Możliwe, że chodziło o formę podatku drogowego.

${ }^{38}$ Por. Historia Nestoriana, PO IV 300.

${ }^{39}$ Por. tamże, s. 301.

${ }^{40}$ Por. tamże, s. 303.

${ }^{41}$ Por. tamże, s. 305.

${ }^{42}$ Por. tamże, s. 303-304; zob. P. Peeters, La date du martyre de S. Siméon, archevêque de Séleucie-Ctésiphon, AnBol 56 (1938) 118-143; M.J. Higgins, Date of the martyrdom of Simeon bar Sabbae, „Traditio” 11 (1955) 1-36; R.W. Burgess - R. Mercier, The Dates of the martyrdom of Simeon bar Sabba 'e and the 'Great Massacre', AnBol 117 (1999) 9-66.

${ }^{43}$ Por. Historia Nestoriana, PO IV 304-305.
} 
Po męczeńskiej śmierci metropolity Szapur zaostrzył represje i zarządził, że ci chrześcijanie, którzy nie wyrzekną się swojej wiary, zostaną pozbawieni życia. Według Chronica Seertensis w całym Kościele perskim zginęło 160 tysięcy męczenników. Widząc tak wielkie tłumy chrześcijan gotowych na śmierć, król wstrzymał ich prześladowanie, aby nie stracić wymaganych podatków ${ }^{44}$.

Każda z analizowanych relacji prześladowań chrześcijan perskich za panowania Szapura II wydaje się być interesująca i godna uwagi. W swojej $\mathrm{Hi}$ storii Kościoła Sozomen zaakcentował rolę czynników zewnętrznych w genezie i rozwoju prześladowań Kościoła w Persji IV wieku (magowie i Żydzi). Nestoriański autor Chronica seertensis również zwrócił uwagę na udział tych grup w kształtowaniu polityki antychrześcijańskiej perskiego władcy, jednak w swoim ujęciu dodatkowo rozwija refleksję teologiczną: prześladowania należy odczytywać jako czas próby, umocnienia wiary oraz wezwanie do nawrócenia. Podobną koncepcję historio-zbawczą w teologii martyrologicznej, negatywnie jednak oceniająca postawę metropolity Symeona, naświetlił Afrahat w swoich Mowach, zwłaszcza w Liście Synodalnym.

\section{THE ATTITUDE OF PERSIAN CHRISTIAN CHURCH DURING THE PERSECUTION OF SHAPUR II}

\section{(Summary)}

The subject of this article deals with Persian Christians in the period of the persecution of Shapur II. The ruler derived from the Sassanid dynasty had governed the Persian Empire since 309 to 379 and on that time of his reign Sassanid Empire saw its first golden era.

The three source accounts were analysed: Demonstrations of Aphrahat, The History of the Hermias Sozomenus and Chronica Seertensis - nestorianical source dated from the IX or X century. Each of analysed reports concerning the persecution of the Persian Christians appears to be interesting and noteworthy. In his Church History Hermias accepted the role of external factors in origin and turn of events of Church persecution in Persia in the IV century (magicians and Jews). Nestorian author of Chronica Seertensis has also made observations of these groups in forming the antichristian politics of the Persian ruler but besides that he even expands theological reflection: the persecution should be interpreted as the time of trial, strengthening the faith and calling on to convert. The Aphrahat in his Demonstrations, particularly in his Synodical Letter had briefed the similar historical-redemptive conception in the martyr theology but judging the posture of Simeon negatively.

\footnotetext{
${ }^{44}$ Por. tamże, s. 304-305.
} 